\title{
Assessment of stump invagination versus simple ligation in open appendicectomy
}

\author{
S. Khan \\ Department of Surgery, NGMC Teaching Hospital, Nepalgunj, Nepal \\ Correspondence to: Dr. Salamat Khan, Department of surgery, NGMC Teaching Hospital, Nepalgunj, Nepal.
}

Email:drsalamatkhan63@yahoo.co.uk

\begin{abstract}
Introduction: Operation of appendix is very common abdominal surgery that is done by general surgeons. Some surgeon prefer to invaginate the appendix stump while others don't. Aim of the study was to compare the technique of ligation and invagination of the appendix stump with simple ligation of the appendix stump during appendicectomy for acute appendicitis.

Methods: A prospective comparative study of 150 appendicectomies were done in the Department of General Surgery, Nepalgunj medical college (NGMC),Nepalgunj,Nepal from June 2001-May 2007in unit III. All patients with uncomplicated and complicated acute appendicitis who underwent open appendicectomy and had appendicular stump for ligation and invagination or simple ligation, were divided into two groups. In group-I ligation with invagination and in group-II, simple ligation of appendix stump was carried out. Patients were followed up for 3-6 months to check the development of complications

Results: Both groups were similar with respect to age and sex. Invagination of the stump after ligation of the stump was done in 70 patients while simple ligation was done in 80 cases. The incidence of postoperative pyrexia (18.57\% and $22.5 \%)$, wound infection (27.15\% and $30.0 \%$ ) and postoperative paralytic ileus (25.71\% and $27.5 \%$ ) was in group-I and group-II respectively.
\end{abstract}

Conclusions: Simple ligation of appendix stump is as safe a procedure as ligation and invagination of appendix stump during appendicectomy.

Keywords: Acute appendicitis, appendix stump, invagination, simple ligation

\section{Introduction}

Acute appendicitis (AA) is one of the commonest abdominal emergencies encountered in and around Kathmandu valley. ${ }^{1}$ The incidence of AA is $0.15 \%$ in males and $0.19 \%$ in females, with an overall lifetime risk of 6-20\%., Clinically, AA was recognized since $16^{\text {th }}$ century and it was known as 'perityphlitis' (associated with severe cecal inflammation) but first successful appendicectomy was reported in $1736 .{ }^{4}$ 150 years later, in 1886, Reginald Fitz first reported the role of surgical removal of inflamed appendix as a curative treatment. ${ }^{3,4}$ Three years later, in 1889, Charles McBurney described the importance of early appendicectomy in his presentation before the New York Society of Surgeons. After five years, he devised his popular muscle splitting incision, which still today bears his name. Since then, appendicitis has been the commonest surgical emergency. The technique of appendicectomy may vary from surgeon to surgeon or from center to center, starting from skin incision to the ligation and invagination of appendicectomy stump. Throughout the last century, the optimum management of appendicectomy stump has frequently been discussed and in 1937, a detailed historical review was made by Ochsner and Lilly. ${ }^{5}$ After ligation or transfixation of the appendix 
stump, some surgeons invaginate the stump by means of a purse-string stitch or a Z-stitch or doubly invaginate the stump but some times, it is not done because of cecal inflammation or sloughing of appendix from the base. But there was no clinical study based work which can support the non invagination of the stump. Simple ligation without invagination was probably introduced by Kronlein in $1884 .{ }^{5}$ This method was used by some surgeons but others have criticized it as leading to increased incidence of wound infection, slippage of ligature and peritoneal adhesions. Theoretically, every surgeon has his own justifications of the operating procedure. No study was conducted on this controversy at our institute. The aim of the study was to compare the outcome of the two techniques of open appendicectomy: invagination with simple ligation of the appendix stump in a clinically prospective, randomized study.

\section{Methods}

This is a prospective, randomized, comparative study conducted in surgical department unit-III of NGMC, Nepalgunj, Nepal from June 2001 to May 2007. All the cases diagnosed as acute appendicitis and its complications (perforation and gangrene) who underwent surgery and had their appendix stump either ligated and invaginated or simply ligated, were included in the study. Patient whose appendix was sloughed from the base and no appendix stump was available to ligate was excluded from the study. Patients were randomly divided into two groups. Group I consists of cases where appendix stump were ligated and invaginated by purse string stitch with $2 / 0$ chromic catgut while group II consists of cases where appendix stump was simply ligated with chromic catgut. All the cases were operated by senior consultant and given similar post operative antibiotic protocol. The patients were followed-up for an average of six months post operatively to check any development of complications. Their postoperative outcomes were compiled and analyzed.

\section{Results}

Total number of cases operated for acute appendicitis and its complications were 155 . Out of them, only 150 cases were included because five cases had no appendix stump for ligation as it was sloughed from base. So they were excluded from the study. Out of 150 cases, 70 cases were treated by ligation and invagination of appendix stump (Group I) and 80 cases were treated by simple ligation without invagination of appendix stump (Group II) (Table 1). Post-operative pyrexia was observed in $18.57 \%$ in Group I and 22.5\%in Group II. This difference is not statistically significant ( $\mathrm{p}>0.05)$. Post operative wound infection was observed in $27.1 \%$ and $30.0 \%$ in Group I and Group II respectively ( $p>0.05$ ). Post operative paralytic ileus was observed for $24-48$ hours in $8.75 \%$ and $10.0 \%$; for $48-72$ hours in $11.42 \%$ and $11.25 \%$ and for $>72$ hours in $5.7 \%$ and $6.25 \%$; in Group I and Group II respectively ( $p>0.05$ ). The incidence and duration of ileus is higher than in previous studies. This difference is because of inclusion of other group of cases (AG, AP) apart from simple AA. Hospital stays in both the groups were similar in average days. Not a single case of fistula, residual abscess, intestinal obstruction was observed in both the groups.

Table 1: Demographic characteristics of the cases treated by appendicectomy

$\begin{array}{lll}\text { Characters } & \begin{array}{c}\text { Patients treated by open appendicectomy } \\ \text { Group I }\end{array} & \begin{array}{l}\text { Group II } \\ \text { Age (yrs) }\end{array} \\ \quad \text { Mean } & 29.98 & 30.78 \\ \text { Range } & 11-70 & 8-60 \\ \text { Sd } & 8.8 & 9.8 \\ \text { Sex } & & \\ \quad \text { Male } & 48 & 58 \\ \begin{array}{l}\text { Female } \\ \text { Per-operative groups } \\ \text { of acute appendicitis }\end{array} & 22 & 27 \\ \begin{array}{l}\text { Simple AA } \\ \text { Apendicular } \\ \text { gangrene (AG) }\end{array} & 56 & \\ \text { Appendicular } & 2 & 62 \\ \text { perforation (AP) } & 12 & 3\end{array}$

Table 2: Incidence of post-operative complications in both groups $(\mathrm{n}=150)$

\begin{tabular}{|c|c|c|c|}
\hline Complications & $\begin{array}{l}\text { Group } I(n=70) \\
\text { No. }(\%)\end{array}$ & $\begin{array}{l}\text { Group II } \\
(\mathrm{n}=\mathbf{8 0}) \\
\text { No.(\%) }\end{array}$ & p-value \\
\hline Pyrexia & $13(18.57)$ & $18(22.5)$ & $>0.05$ \\
\hline $\begin{array}{l}\text { Postoperative wound } \\
\text { infection }\end{array}$ & 19(27.10) & 24(30.0) & $>0.05$ \\
\hline Paralytic ileus & $6(8.57)$ & & $>0.05$ \\
\hline 24-48 hrs & $8(11.42)$ & $8(10.0)$ & \\
\hline $48-72$ hrs & $4(5.71)$ & $9(11.25)$ & \\
\hline$>72$ hrs & & $5(6.05)$ & \\
\hline Fistula & Nil & Nil & \\
\hline Residual abscess & Nil & Nil & \\
\hline $\begin{array}{l}\text { Intestinal obstruction } \\
\text { due to adhesions }\end{array}$ & Nil & Nil & \\
\hline Other complications & Nil & Nil & \\
\hline $\begin{array}{l}\text { Hospital stay } \\
\text { (average days) }\end{array}$ & 5.5 & 5.4 & \\
\hline
\end{tabular}


Stump invagination versus ligation in appendicectomy

\section{Discussion}

Acute appendicitis is the commonest surgical emergency in the developed countries and in Nepal. ${ }^{1}$ It is common in the second decade of life. ${ }^{6}$ Fascinating new operative techniques have emerged and replaced the conventional procedures but in the case of appendicitis, we are still relying on the traditional method of appendicectomy in our institute. Laparoscopic appendicectomy is being done less often and started recently in our institute. During appendicectomy, some surgeons do simple ligation of the appendix stump while others still prefer to invaginate it by a purse-string suture or a Z-stitch. The reasons given for this invagination of stump are safety against slipping of ligature from the stump or blow out of appendix stump, less chances of peritonitis from spillage of pathogens from remaining the stump, less incidence of post operative wound infection, better healing of gut by formation of granulation tissue and collagen from the serosal layer of caecum. ${ }^{7}$ On the other hand, simple ligation is simpler, less time consuming and leaves intact the anatomy of caecal wall, with no difference in the incidence of postoperative wound infection or paralytic ileus. ${ }^{8}$ However, there are reports of more residual abscesses over the wall of caecum due to invagination of stump. Besides the deformation (filling defect) may lead to the suspicion of a neoplasm. ${ }^{9,10}$ Simple ligation, of course, obviates these misinterpretations on colonoscopy. There was no significant difference in the incidence of postoperative pyrexia (18.57\% and $22.5 \%$ ), wound infection (27.1\% and $30.0 \%$ ) in both the groups in our study. Similar observations were also reported by previous workers. ${ }^{5,8-}$ 11,13-15 But the incidence and duration of post-operative paralytic ileus was more as compared to other studies. This difference is because of inclusion of appendicular gangrene and perforation and peritonitis cases in the present study. ${ }^{8,9,11-14}$ No serious post-operative complication was noticed in both the groups in this study; similar findings were reported by different authors in the international literature. ${ }^{5,8,9,11}$

\section{Conclusions}

From the above study, it can be concluded that there is no advantage of invagination over simple ligation of appendix stump in appendicectomy which is similar to the report of previous studies. ${ }^{5-11,13-15,17}$

\section{References}

1. Chhetri RK, Shrestha ML. A comparative study of preoperative with postoperative diagnosis in acute abdomen. Kathmandu Univ Med J (KUMJ). 2005 AprJun;3(2):107-10.

2. Simpson J, Scholefield JH. Acute appendicitis. Surgery International. 2002;58:153-7.

3. Jones PF. Suspected acute appendicitis: trends in management over 30 years. Br J Surg. 2001 Dec;88(12):1570-7.

4. Kozar RA, Roslyn JJ. The appendix. In: Schwartz SI, Shire GT, Spencer FC, Daly JM, Fischer JE, Galloway AC, editors. Principles of surgery. 7th ed. Mcgraw-hill: London; 1999. p. 1383-94.

5. Engstrom L, Fenyo G Appendicectomy: assessment of stump invagination versus simple ligation: a prospective randomized trial. Br J Surg. 1985;72:971-2.

6. Amir M, Shami I. Analysis of early appendicectomies for suspected appendicitis: a prospective study. J Surg 1992;3(4):25-88.

7. Ellis BW. Acute appendicitis. In: Ellis BW, Brown SP, editors. Hamilton bailey’s emergency surgery. 12th ed. Oxford: Butterworth-Heinemann Ltd; 1995. p. 411-23.

8. Lavonius MI, Liesjarvi S, Niskanen RO, Ristkari SK, Korkala O, Mokka RE. Simple ligation vs stump inversion in appendicectomy. Ann Chir Gynaecol. 1996;85(3):222-4.

9. Jacobs PP, Koeyers GF, Buryninckx CM. Simple ligation superior to inversion of the appendiceal stump; a prospective randomized study. Ned Tijdschr Geneeskd. 1992; 136(21):1020-3.

10. Engstrom L, Fenyo G Appendicectomy: assessment of stump invagination versus simple ligation: a prospective randomized trial. Br J Surg 1985; 72(12):971-2.

11. Kingsley DPE. Some observation on appendicectomy with particular reference to technique. Br J Surg. 1969;56:491-6.

12. Sinha AP. Appendicectomy: an assessment of the advisability of stump invagination. Br J Surg. 1977;64(7):499-500.

13. Dass HP, Wilson SJ, Khan S, Parlade S, Uy A. Appendicectomy stump: 'to bury or not to bury'. Trop Doct. 1989;19(3):108-9.

14. Osime U, Ofili OP, Duze A. A prospective randomized comparison of simple ligation and stump invagination during appendicectomy in Africans. J Pak Med Assoc. 1988;38(5):134-6. 
15. Watter DAK, Walker MA, Abernethy BC. The appendix stump: should it be invaginated? Ann Roy Coll Surg Engl. 1984;66:92-6.

16. Bhopal FG, Khan JS, Iqbal M. Surgical audit of acute appendicitis. J Coll Physicians Surg Pak. 1999;9(5): 223-6.

17. Drincovic N. Age distribution and clinical characteristic in acute appendicitis. Vojinosanit Pregl. 1991;48:115-9.

18. Chaudhary IA, Samiullah M, et al. Is it necessary to invaginate the stump after appendicectomy? Pak J Med Sci. 2005;21(1):35-8. 